DOI: $\underline{10.15826 / \text { itr.2015.1.1.007 }}$

УДК 338.45:622

Ponkratov V.V., Candidate of Economic Sciences,

Financial University under the Government of the Russian Federation

Moscow, Russia

\title{
OIL PRODUCTION TAXATION IN RUSSIA AND THE IMPACT OF THE TAX MANEUVER
}

\begin{abstract}
The author reflects on the current taxation of oil production in Russia, the mechanisms and effects of the tax maneuvers taken in 2013-2014 in the oil industry. In the near future, members of the Customs Union will draw up a unified policy in the area of fuel and energy complex and harmonize the system of export custom duties on oil and petrochemical products. The author formulates proposals for improving the tax system of oil production in Russia, taking into account its developmental prospects, the existing resource restrictions, as well as significance for the budget. In 2011-2014, the Russian Government paid special attention to the issue of improvement of MET, but the latest innovations entail domination of the fiscal function of this tax. The situation in the oil sector demands the opposite - there is a growing need for investments into the development of oil fields in new oil and gas provinces, and the development of transport and refinery capacities. While working out the concept of taxation of crude hydrocarbons extraction, the following approaches should be used: taxation of end results of companies' performance; stimulation of the rational use of natural resources and the fullest extraction of the main and associated components; economic and budgetary efficiency; simplicity of administration. Suggestions are made about how to improvet the Russian system of taxation of extraction of crude hydrocarbons with regard to such taxes as MET, income tax, export duty, and royalties.
\end{abstract}

Keywords. Taxation of crude hydrocarbon extraction; mineral extraction tax; custom duty; tax maneuver; resource potential of the oil-and-gas industry of Russia; harmonization of taxation within the Customs Union.

From an international perspective, the distinctive feature of the Russian taxation system in oil-and-gas industry is export duties. Another major difference lies in the fact that the mineral extraction tax rate (hereinafter referred to as MET) in respect to hydrocarbon resources is specific and weakly differentiable.

Twelve years of experience in implementing MET show that the current system of resource taxes is inadequate to the role the oil-and-gas industry plays in Russia either in fiscal or regulating terms. The system aims to confiscate the current excess profits, caused by the positive price conditions on the raw materials market.

This approach can be justified only in respect to the projects that involve high investmentsm but it is absolutely unsuitable for such capital-intensive projects as the development of new fields in the oil-andgas provinces, and the northern seas shelves. There are no incentives to develop the stripped wells, but numerous tax payments. This does not solve the problem of the natural rent withdrawal into the budget. There are still no real incentives to attract investments into prospecting, recognition, and development of hydrocarbon fields.

The major tasks of resource taxation withdrawal of rent income and stimulation of efficient use of resources - are are not solved effectively.

The MET innovations implemented in 2008-2015 resulted in the drastic dominance

\footnotetext{
${ }^{1}$ Ponkratov Vadim - Candidate of Economic Sciences, Director of the Center of financial policy, Financial University under the Government of the Russian Federation (Russia, 125993, Moscow, Leningradsky Av., 49); ); e-mail: vadim.ponkratov@gmail.com.
} 
of the fiscal function. It is primarily due to the high degree of dependence of the Russian economy and the budget revenues on the export of raw materials.

The role of the Russian oil industry in the country's economy and government budget revenues. In 2014, crude oil production was 526,8 mill. tons, which is $0,6 \%$ higher than in 2013. Nnatural gas extraction in 2014 decreased by $4.2 \%$ in comparison with 2013, equalling 650,236 bn. cubic meters. The average price of Urals in 2014 decreased by $9,5 \%$ and was $\$ 97,60$ per barrel (in 2013, it was $\$ 107,88$ per barrel). In December 2014, the oil price was $\$ 61,07$ per barrel, which is $44,4 \%$ lower than in December 2013.

According to the Federal Customs Service of the RF, in 2014 the total export from the Russian Federation was estimated at $\$ 496,94$ bn., which included: crude oil $\$ 153,88$ bn., oil products $-\$ 115,65$ bn., natural gas - $\$ 54,73 \mathrm{bn}$. Thus, the crude hydrocarbon and its products account for $65,25 \%$ of the Russian export. It shows that the Russian economy is still based on raw materials and depends on the export of energy resources.

In 2014, the consolidated budget of the Russian Federation received 12 670,2 billion rubles, which is $11 \%$ higher than in 2013 . In 2014, the amount of MET in the consolidated budget of Russia was equal to 2,904.2 billion rubles, which is $12.8 \%$ higher than in 2013 (Table). This is determined by the MET rate adjustment.

The percent of the MET in the consolidated budget of the Russian Federation is remarkable, but not predominant. It creates a misleading impression that the budget is not that dependant on the hydrocarbon revenues. But the situation becomes different if one adds the export duty on oil, oil products, and gas to the budget equation. It should be remembered that in 2005 it was eliminated from the tax list and is now considered in the "Revenues from Foreign Trade" division.
In 2014, the federal budget received $4,597 \mathrm{bn}$. rubles from the export customs duties on crude oil, natural gas, and petroleum products. Miscellaneous export customs duties (export of metal, military equipment, machinery and equipment, timber, light industry goods, agricultural products, and products of other branches of the Russian industry) equalled $40,1 \mathrm{bn}$. rubles only $(0,87 \%)^{2}$.

According to the main thrusts of the budget policy in 2015 and 2016-2017, oil and gas revenues are predicted to be $48 \%$, which corresponds to the pre-crisis rates and demonstrates the crucial dependence of the budget on the hydrocarbon markets prices. Such dependnce was evident during the acute phase of the world financial crisis in 2008. Taking into consideration all the uncertainties caused by the hydrocarbon markets prices, the financial stability of the country and its economical growth are facing serious threats. It should be noted that over the past decade the oil exchange prices have been changing in accordance with the laws of the market of derivative financial instruments, not the market of traditional raw products. That is why it is almost impossible to predict the dynamics with a reasonable degree of probability.

One might ask if Russia is able to ensure the level of welfare of its citizens, that would correspond to the standards of developed countries, by simply redistributing the assets received from the production of hydrocarbons

The world experience shows that two baseline scenarios are possible:

1. "Oil curse" - negative effects of the "Dutch disease" (the outrunning growth of salaries in comparison with the increase of labor capacity, increase in cost, national currency appreciation caused by currency

\footnotetext{
2 Information about the Consolidated Budget of the Federal Government of the Russian Federation in 2014. [Electronic resource]. - Access mode: http:// www.roskazna.ru/konsolidirovannogo-byudzheta-rf/ (Application date: 26.04.2015).
} 


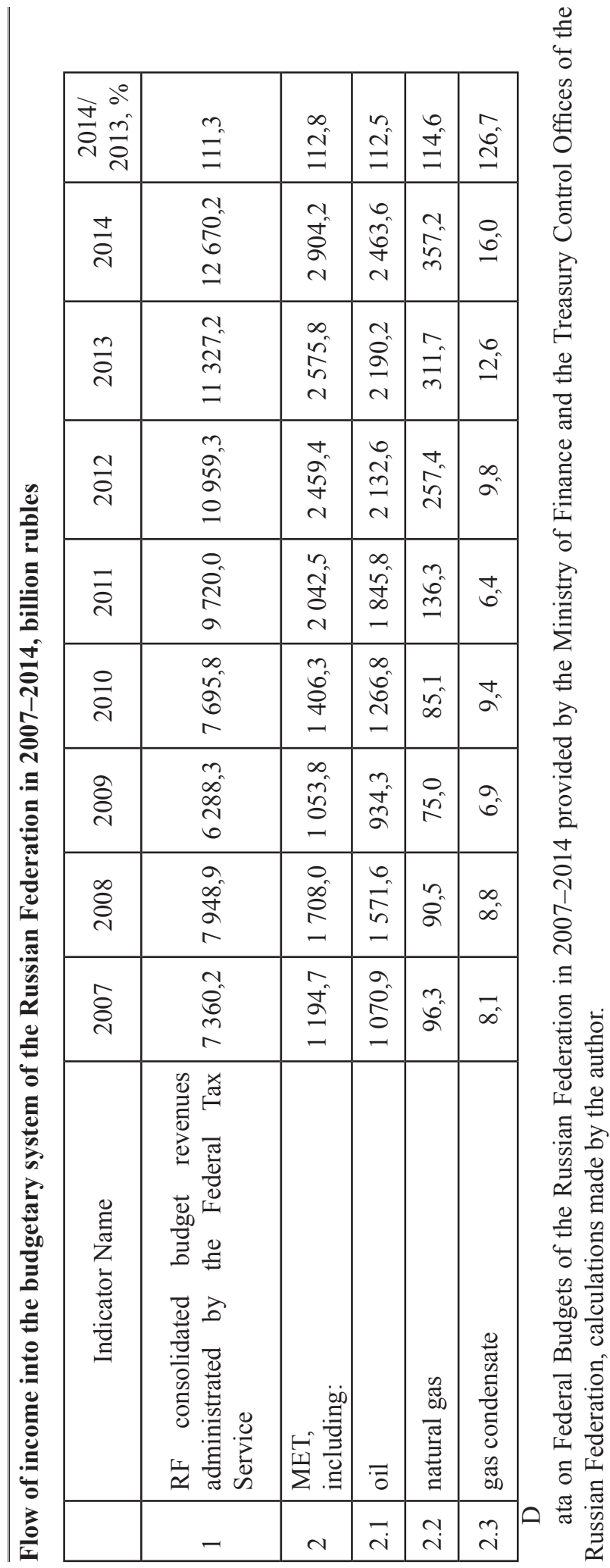




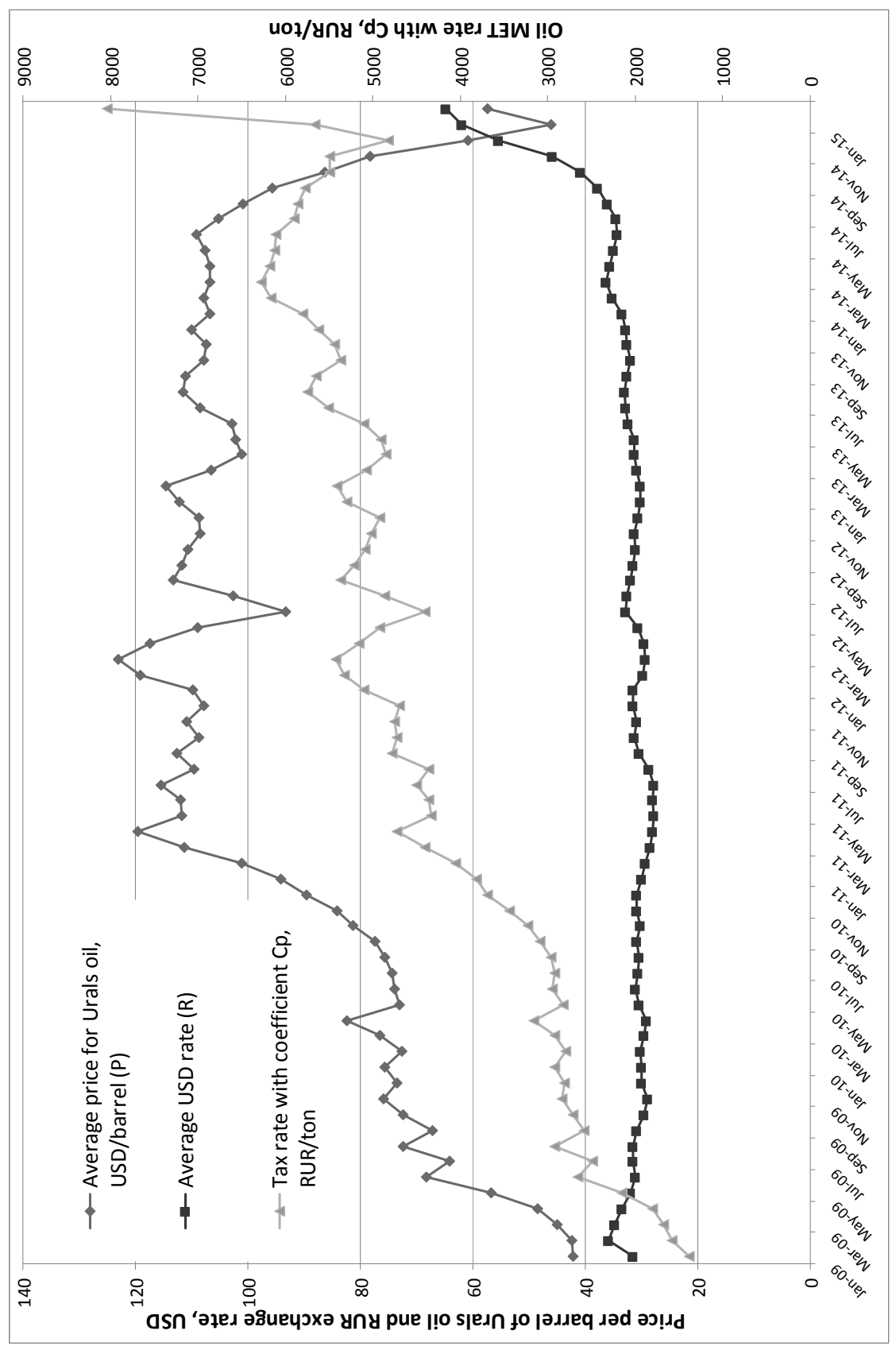

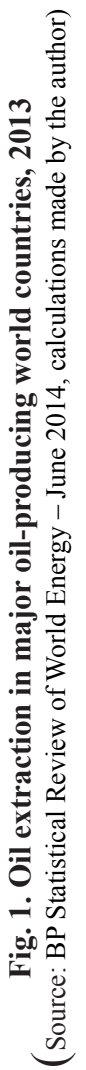


inflows to the oil exporting countries, and as a result the loss of competitive ability of the national manufacturers), and the fact that the political elite has lost the incentives to improve the quality of the economic and social policies.

2. "Oil welfare" of Norway, the United Arab Emirates, Kuwait, Qatar, Saudi Arabia. High living standards of these counties are associated with the state financial allocations based of highly paternalistic ideas of non-refundable benefit payments to the citizens as well as delivering a wide range of social services. Meanwhile, the figures show that it is inappropriate to compare Russia with the "petrostates" mentioned above from the perspective of the models of social and economic policies ${ }^{3}$. The main reason is Russia's large population.

The main characteristic of the successful "petrostates" is that the population of each of them does not exceed 5 mill. people (except for Saudi Arabia which has a population of 28 mill. people due to the incomparably large oil and gas potential). This makes 20 tons of hydrocarbons per each citizen a year.

Russia's share in world oil production is close to $12 \%$, and in gas production, over $25 \%$ (in total, over $1,1 \mathrm{bn}$. tons of crude oil equivalent a year). But in 2012 the amount of extracted oil was only 3,67 tons per person. It should be taken into account that Russia is a country with a huge territory and an industrial economic structure, which demands to support the resource-intensive transport infrastructure and conditions the strong domestic energy demand.

In total, Russian economy consumes almost 550 mill. tons of hydrocarbons a year. No wonder that, as a result, the annual volume of net export equals about 4 tons of oil equivalent per one citizen of Russia (the results of 2012). It means that our capabilities in the area of converting the national hydrocarbon potential into the national prosperity are knowingly restricted.

\footnotetext{
${ }^{3}$ Milov, V. Can Russia become the oil heaven // Pro et Contra. - 2006. - № 2-3.
}

Some basic calculations show that, given the current extra-high world export prices, when Russian oil costs $\$ 100$ a barrel, the revenue from the export of 4 tons will amount to $\$$ 3200 a year or $\$ 2500$ with due regard to expenses.

The raw materials base of the Russian oil industry is estimated to comprise $10 \%$ of the world base. In this, Russia is behind Saudi Arabia, Canada and Iran. However, Russia has great prospects for developing the raw material base, as its oil resources comprise more than a third of the world resources. Most of them are the prospective resources of the $\mathrm{C}_{3}$ category and are estimated at 12 bn. tons. The regional distribution of oil and condensate is random. In 2013, as well as in the previous years, two thirds of the Russian oil was developed in the West Siberian oil and gas bearing basin; a major part of it was extracted in Khanty-Mansi Autonomous Okrug. It should be noted, though, that the role of Khanty-Mansi Autonomous Okrug in the area of oil extraction has diminished over the past years. This has been caused by a decrease in flow rates of the wells at the oil fields, many of which have been being developed for more than 40 years. Another reason is that the field characteristics of new facilities are becoming worse. More than half (57 $\%$ in 2013) of the oil of the West Siberian basin is extracted at 20 fields: 18 are situated in Khanty-Mansi Autonomous Okrug, one is in Yamalo-Nenets Autonomous Okrug, and one (Vankorskoye) is in Krasnoyarsk Krai. Since 2007, the Priobskoye Field has been a leader in oil extraction; in 2013 the field was producing 41,3 mill. tons, or $8 \%$, of the total Russian oil. The Samotlor Field that used to be a leader, now occupies the second place, with 25,7 mill. tons. The oil reserves have been depleted for more than $70 \%$. The Volga-Ural oil and gas basin annually supplies about $20 \%$ of the total amount of oil extracted in the Russian Federation. In 2013, it equalled $21,3 \%$, or 103,4 mill. rubles. The Romashkino Field, the biggest oil field in Tatarstan, plays the main role in the area of oil extraction, despite the fact that its oil 
reserves are depleted for almost $88 \%$. The amount of produced oil equals 103,4 mill. tons. The rest of oil is extracted at nearly a thousand fields ${ }^{4}$.

It is important to note the following problems in the oil-and-gas industry in Russia: the resource gluttony (low coefficient of oil and gas extraction), lack of integral hydrocarbon processing technologies (flaring of associated petroleum gas), predicted depletion of the main oil and gas fields of the West Siberian provinces; hydrocarbon production cost development in the new provinces; insufficient infrastructure for the diversification of hydrocarbons export routes; heavy wear of the transport infrastructure and processing industry; low processing depth.

To sustain the volume of hydrocarbons it is important to:

- develop the fields in the new oil and gas provinces that do not have the appropriate infrastructure. These provinces include the shelves of the north and far east seas, territories north of $65^{\circ}$ North latitude ${ }^{5}$;

- develop hard-to-recover oil reservoirs, including high-viscosity oil; the Achim and Valanzhinian gas condensate fields; natural shale gas fields; high-sulphur gas fields, lowpressure gas fields, and the fields with a high percentage of helium.

Tax maneuver in the oil industry of Russia - version 2014. In September 2013, Russia experienced the $2^{\text {nd }}$ "tax maneuver" in the oil area. This maneuver featured an increase in the applied rate of severance tax on oil production and a decrease in rates of export customs duties on crude oil and rates

\footnotetext{
4 Analytical report "The condition of the mineral and raw material base of oil and condensate in the Russian Federation, 01.01.2014" [Electronic resource]. - Access mode: http://www.mineral.ru/ Facts/russia/156/506/3 01_oil.pdf (application date: 26.04.2015).

5 Energy strategy of the Russian Federation for the period up to 2030 .
}

of export duties on clean petroleum products (except for petrol).

These innovations were set forth in the Federal Law of 30.09.2013 № 263-FZ “On Amending Article 26 of Part Two of the Tax Code of the Russian Federation, and Article 3.1 of the Law of the Russian Federation "On Customs Tariff".

In the case of extracting the desalted, dehydrated and stabilized oil, the MET rate is 493 rubles (for the period from 1 January to 31 December, 2014), 530 rubles (for the period from 1 January to 31 December, 2015), 559 rubles (for the period from 1 January to 31 December, 2016) for 1 ton of extracted oil. The indicated tax rate shall be multiplied by different coefficients.

The most drastic changes have affected the calculation of MET rates in relation to natural gas and gas condensate. Before, those rates had ben absolute values, but starting from 1.07.2014, a calculation formulae has been used. Starting from 1 July, 2014, MET rates for natural gas and gas condensate production have been as follows:

- 42 rubles per 1 ton of gas condensate extracted from all the fields with hydrocarbon resources.

- 35 rubles per 1,000 cubic meters of combustible natural gas extracted from all the fields with hydrocarbon resources.

The indicated tax rate is multiplied by the basic value of the oil equivalent (TOE) and the complexity index (CI) that counts for the difficulty of extraction of combustible natural gas and/or gas condensate from hydrocarbon discoveries, defined in accordance with Article 342.4 of the Russian Tax Code. As for combustible natural gas, the product is added to the value that defines costs related to the transportation of combustible natural gas $(\mathrm{TG})^{6}$.

Attempts to calculate the volume of tax liabilities of oil and gas production

\footnotetext{
${ }^{6}$ Federal Law of 30.09.2013 №263-FZ “On Amending Article 26 of Part Two of the Tax Code of the Russian Federation, and Article 3.1 of the Law of the Russian Federation "On customs tariff".
} 
companies have shown that it is hard to implement the mechanisms to measure the MET rate based on the necessity to calculate the interdependent multi-valued coefficients. That is sure to cause problems in tax administration. Moreover, some index values needed to calculate the tax rate are not available to oil and gas production companies.

In 2012, the export customs duties on crude oil were equal to $60 \%$, dropping to $59 \%$ in $2014,57 \%$ in 2015 , and $55 \%$ in 2016.

It should be noted that before this tax maneuver, the Government of the Russian Federation started to pay special attention to the improvement of hydrocarbons taxation system. For example, Government Resolution № 700-p of May $3^{\text {rd }}, 2012$, aims to stimulate extraction of the hard-to-get reserves; it addresses the issue of grading projects by complexity, depending on geological conditions, and features reduced MET rates depending on the complexity category and the reduced export duty rate for super-viscose oil ${ }^{7}$.

The ultimate objective of tax innovations is to involve $2,5 \mathrm{bn}$. tons of reserves into active development. The Resolution has the potential to confront the crisis and provides the possibility to use additionally reduced MET rates and export customs duties and other means of tax and customs and tariffs stimulation regarding the drastic changes of the world market, including the reduction of the Urals oil price on the world market to levels less than $\$ 60$ per barrel, and in force-majeure circumstances defined in accordance with the legislation of the Russian Federation.

To stimulate new shelf projects, Government Regulation № 443-p has been adopted;

\footnotetext{
7 Ordinance of May 3, 2012 № 700-p “On Proposal of the Ministry of Energy of Russia to classify the projects concerning development of the sub-soil containing the hard-to-get oil reserves defined on the basis of permeability index and oil viscosity" [Electronic resource]. - Access mode: http://правительство.pф/ gov/results/18899/ (Application date: 26.04.2015).
}

it concerns grading projects by complexity depending on the geographical position. The main innovations concern the exemption of companies extracting hydrocarbons at new sea fields from export customs duty, and introduction of ad valorem MET tax rates depending on complexity category ${ }^{8}$.

Another objective of the tax innovations is to begin an active geological investigation in the region with expected hydrocarbon resources of $100 \mathrm{bn}$. tons of reference fuel.

According to the major directions of the tax policy of the Russian Federation for 2015 and 2016-2017, efforts to implement the tax maneuver will continue. All further steps will be defined in view of the agreements reached between the Russian Federation, the Republic of Belarus, and the Republic of Kazakhstan, concerning the functioning of oil and oil products markets within a unitary economic space?.

It should be noted that Russia has a large territory that lies in the northern part of the continent and has an industrial economic structure; these facts define the high domestic demand for energy materials. As the MET base rates go up, the tax liabilities of oil producing companies grow dramatically. This affects the price of fuel and energy resources within the country and leads to a multiplicative price growth in the basic industries, prices in transport and agricultural areas.

In September 2014, an government version of the tax maneuver in the oil area was endorsed, which was later formalized in keeping with Federal Law №366-FZ of 24.11.2014 ${ }^{10}$. The plan is to implement the maneuver within 3

\footnotetext{
8 Decision of Government of the Russian Federation from April 12, 2012 № 443-p "On stimulation of the new shelf projects".

${ }^{9}$ Project of the major directions of the tax policy of the Russian Federation for 2015 and a period of 20162017 [Electronic resource]. - Access mode: http:// www.minfin.ru/ru/tax_relations/policy/index.php (Application date: 26.04.2015).

${ }^{10}$ Federal Law of 24.11.2014 N366-FZ «On Amending Part Two of the Tax Code of the Russian Federation and specific legislative acts of the Russian Federation».
} 
years - from 2015 to 2017. In 2015, the MET will equal $766 \mathrm{rub} /$ ton against an earlier value of $530 \mathrm{rub} / \mathrm{ton}$. In 2016, the MET will equal $857 \mathrm{rub} /$ ton against $559 \mathrm{rub} / \mathrm{ton}$, and in 2017$919 \mathrm{rub} / \mathrm{ton}$.

It is expected that the export customs duty for crude oil will be reduced faster than the budgeted parameters stipulated by Federal Law of 30.09.2013 № 263-Ф3, and will equal $42 \%$ in $2015,36 \%$ in 2016 , and 30 $\%$ in 2017.

The export customs duty for diesel fuel will equal $48 \%$ in $2015,40 \%$ in $2016,30 \%$ in 2017. The export customs duty for petrol will equal $78 \%, 61 \%$, and $30 \%$, respectively. The fee for black oil fuel will reach 100 $\%$ in 2017.

The formula to calculate $M E T$ applicable to oils has been changed. Before January 1, 2015, the following formula to calculate the MET rate was applied:

$$
M E T=493 \cdot C_{p} \cdot C_{d} \cdot C_{r} \cdot C_{d e} \cdot C_{r d},
$$

where $C_{p}$ is a coefficient that defines fluctuations in world oil prices;

$C_{d}$ is a coefficient that measures the level of depletion of reserves of a specific subsurface site;

$C_{r}$ is a coefficient that measures the level of reserves of a specific subsurface site:

$C_{d e}$ id a coefficient that measures the degree of difficulty of oil extraction;

$C_{r d}$ is a coefficient that measures the level of depletion of a specific reservoir.

Federal Law №366-FZ of 24.11.2014 has defined the following formula to calculate MET:

$$
\begin{aligned}
M E T & =766 C_{p}-520 \mathrm{x} \\
& \mathrm{x} C_{p}\left(1-C_{d} \cdot C_{r} \cdot C_{d e} \cdot C_{r d} \cdot C_{c a n}\right) .
\end{aligned}
$$

The formula features a new coefficient besides those stipulated by Federal Law № 263:

$C_{c a n}$ is a coefficient that defines the oil production region and oil properties.

Except for $\mathrm{C}_{\mathrm{p}}$, all the other coefficients in the formulae mentioned above are reduction coefficients. The coefficient that measures fluctuations in world oil prices was 11.1456 in 2014. Let us consider a typical situation when an oil producing company has no reason to apply other MET rate coefficients. In this case, the MET rate will be $493 \mathrm{x}$ $11.1456=5495 \mathrm{rub}$. per 1 ton of the desalted, dehydrated and stabilized oil. According to the new version of Article 342 of the Tax Code of the Russian Federation, the real MET rate will equal 8,538 rub. per ton of oil. Thus, the MET growth is 3,043 rub., which will lead to the proportional growth of oil prices in the domestic market.

In 2015 the budget is expected to receive 198,3 bn rubles less than stipulated by the Budget Law covering the year 2014 and the 2015-2016 period (a 120 bn. increase in 2016, and a 77,8 bn. increase in 2017).

Calculations show that the parameters of the tax maneuver will cause a reduction of the refinery margin from $\$ 55$ to $\$ 30$ per ton.

The figure shows that up to 2014 the dynamics of oil prices fully corresponded to the MET ruble rate. This correspondence was possible due to the stability of the ruble exchange rate against the US dollar, which is the second component of the $\mathrm{C}_{\mathrm{p}}$ calculation. The situation changed in the second half of 2014 , the tax maneuver was made on January 1, 2015, and in February we noted that the MET ruble rate equalled 8,032 rubles per ton with the price of oil at $\$ 57,3$ a barrel. It should be noted that on the absolute peak of oil price in March 2012, the MET rate was 5,427 rubles with the oil price at $\$ 123,2$ a barrel.

Let us convert the oil price from USD/ barrel into rub/ton. In this case, the MET rate data with $\mathrm{C}_{\mathrm{p}}$ looks smooth but still follows the price fluctuations. The share of MET in oil prices raises concerns. From October 2010 to November 2014 the oil prices varied from 80 to $120 \mathrm{USD} / \mathrm{barrel}$, the share of MET was between $17 \%$ and $22 \%$.

The figure shows the intervals of the tax maneuvers - the increase in the tax burden and strong values at the beginning of the year. The latest tax maneuver undertaken in February 2015, when the price of oil was 27,432 rub. per ton, raised concerns, because this rate was identical to the August 2013 oil 


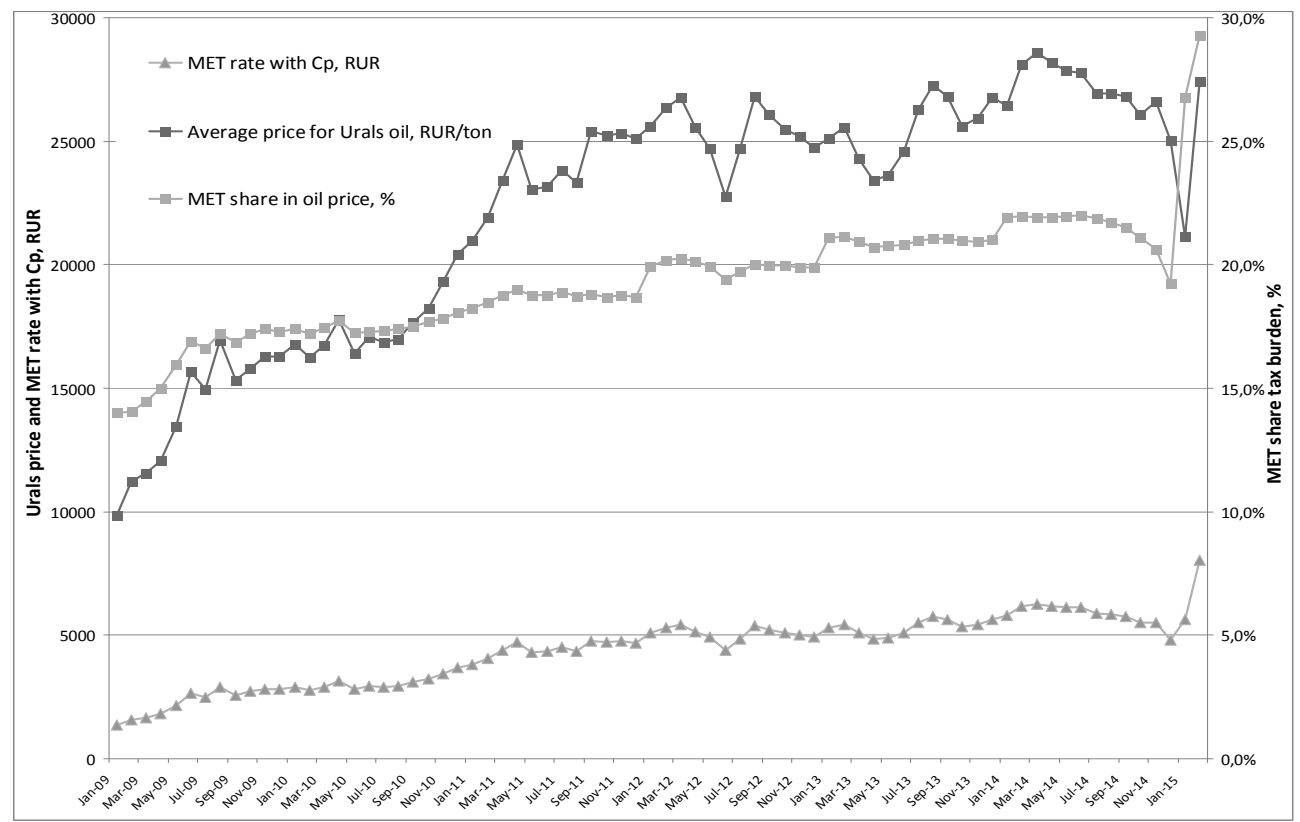

Fig. 2. The dynamics of oil prices, US dollar/ Russian ruble rates, and oil MET rate with $C_{P}$ from January 2009 to April 2015

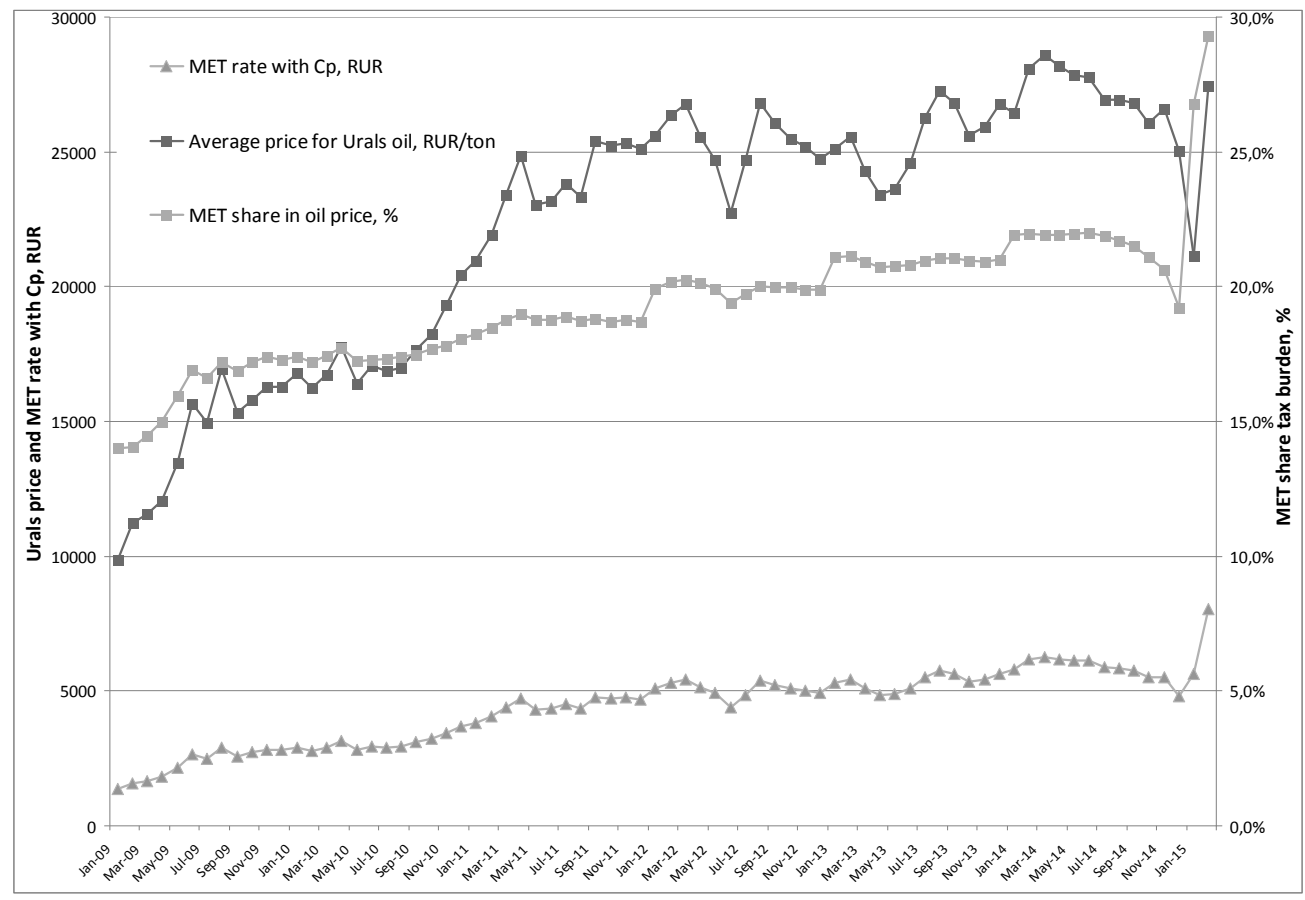

Fig. 3. The dynamics of oil prices in rubles, oil MET rate with $\mathrm{C}_{\mathrm{P}}$ and MET share in oil costs from January 2009 to April 2015 
prices $-27,263$ rub, yet the share of MET had increased from $21,0 \%$ to $29,3 \%$.

Proposals to improve the oil production taxation system in Russia. The level of cumulative tax burden that oil producing companies bear is much higher than that of the companies from other sectors of economy. This is determined by the policy of the Russian Government. To a certain extent, excessive tax burden might be seen as an effort, on the part of the State, to exclude the resource rent that comes in effect when the subsoil user companies extract hydrocarbons. It is important to boost the technological development of domestic economy with the help of rent income and promote its shift from orientation to fuel and raw materials in the world division of labour.

A revision of natural rent should not deprive the fuel and raw materials industry of its competitive capability. We need to find a balance between the interests of the State and the businesses. It is in the public interest to stimulate investments that will have a stronger impact on the economy and the natural and resource capacity. The fact that this rent relates to the State property does not mean that the public interest will be reduced to the exclusion of the rent from the corresponding industries. Natural rent reinvestment made by the industries conforms with the long-term objectives of the State and the businesses ${ }^{11}$.

One of the most urgent necessities today is to stimulate the development of new fields which require high operational and capital expenses and feature complex geological conditions, a necessity to create the infrastructure, and a remote location from the world markets. The calculations made by oil and gas institutions show that the MET benefits are not enough to provide profitability of extraction.

It seems that the oil production tax system of the Russian Federation might

\footnotetext{
11 Ponkratov V.V. Improving oil and gas tax system regarding the hydrocarbon potential of the Russian economy // Taxes and Financial Law. — 2012. — № 7.
}

benefit by using the following instruments:

1 The mineral extraction tax. Importantly, the MET is a royalty by nature - the resource owner receives payment for the use of the resource. The subject of our case is oil extraction from the subsoil of the Russian Federation. In terms of economy, the payment has a form of a fee, not a tax due to its reimbursable character. It is important that the current association of MET with the world market prices be abandoned. The possible ways to do it are as follows:

- $\quad$ associate the price coefficient with the Russian domestic price indicators when calculating the MET rate. The Russian Petroleum Exchange may serve as the main source of information;

- change the application procedure for the coefficient measuring the dynamics of the world prices for oil $\left(C_{p}\right)$. It is economically feasible to apply the $\mathrm{C}_{\mathrm{p}}$ to the base MET only to the export hydrocarbon resources. It is not hard to trace the flow of produced oil, because the transport infrastructure belongs to "Transneft". The subsoil user companies should be obliged to submit relevant information to support the MET rate without $C_{p}$;

- $\quad$ stop applying the price coefficient when calculating the MET rate. In this case, the base MET rate must be a little higher, and the fiscal effect must be transferred to the export customs duty on oil and oil products.

The latter option seems to be the most preferable, but it may be unbeneficial in the event of a sharp drop in oil prices and will require operational flexibility on the part of the Government and the legislators.

There are reasons to continue with the oil MET differentiation depending on the basic criteria, and to take this course as the basic scenario of oil production tax system devel-

\footnotetext{
12 Ponkratov V.V. Improving taxation of oil production // Finances. — 2011. — № 6.
} 
opment. There is a need to expand the benefits applicable to hard-to-get oil reserves ${ }^{12}$.

2 Income tax - the basic tax of the Russian tax system paid by all the economic entities (except those subject to special tax regimes), provided that there is an object of taxation (profit). The possibility of introducing a tax benefit in the form of depletion allowance into the Russian tax regulations ought to be considered. The developed countries actively apply this mechanism to support the profitability and reduce the taxation of profit of specific mining industries.

3 Export customs duty. When a company sells the extracted hydrocarbon resources abroad, it receives extra income resulting from the difference between the domestic and the world prices for energy products.

There is a need to expand the upper limit of the world oil price interval, as stipulated by Para. 4 of Article 3.1 of the RF Law "On the customs tariff", by adding several adjusting intervals: the price interval from 182.5 to $290 \mathrm{USD} / \mathrm{ton}$, from 290 to 450 USD/ton, from 450 to $600 \mathrm{USD} / \mathrm{ton}$, and over $600 \mathrm{USD} /$ ton. It would give the current mechanism the ability to work effectively at the current levels of world oil prices and at medium term prices levels - about 80 USD/barrel (582 USD/ton). It would also be possible to maintain the trend of growth of the customs duty share with an increase in export price.

4 Rentals payment system stipulated by the Subsoil Resources Law. This system should be supplemented with payments made for the right to extract mineral resources, regarding mining, geological and feasibility criteria of the field development. Another option is to enable a better assessment and seizure of rent profit through granting licenses to extract mineral resources.

\section{References}

1. Alexeev, M., Conrad, R. (2009) The Russian oil tax regime: A comparative perspective. Eurasian Geography and Economics, 50 (1), 93-114.

2. BP Statistical Review of World Energy - June 2014.

3. Cremer, H., Gahvari, F., Ladoux, N. (2015). Energy Taxes and oil price shocks. B.E. Journal of Economic Analysis and Policy, 15, Issue 2, 475-501.

4. Chemingui, M.A., Hajeeh, M. (2011). Fiscal policy responses to oil price volatility in an oil-based economy. Public Finance Review, 39 (2), 288-308.

5. Daniel, P., Keen, M., McPherson, C. (2010). The taxation of petroleum and minerals: principles, problems and practice. US, Fiscal Affairs Department, International Monetary Fund. Routledge Taylor \& Francis Group. Pages 1-454.

6. Dieler, J (2013). Evolution of oil taxes: An international perspective. CESifo DICE Report, 11 (2), 53-54.

7. Gaddy, C.G., Ickes, B.W. (2005). Resource rents and the Russian economy. Eurasian Geography and Economics, 46 (8), 159-583.

8. Garnaut R. (1983). Taxation of Mineral Rents. Oxford: Clarendon Press.

9. Golosov, M., Hassler, J., Krusell, P., Tsyvinski, A. (2014). Optimal Taxes on Fossil Fuel in General Equilibrium. Econometrica, 82, Issue 1, 41-88.

10. Hochman, G. Zilberman, D. (2015). The political economy of OPEC. Energy Economics, 48, 203-216.

11. Johnston, D., (1994). International 
Petroleum Fiscal Systems and Production Sharing Contracts. Tulsa, US: PennWell Publishing Company.

12. Milov V. Mozhet li Rossija stat' neftjanym raem [Whether Russia become oil paradise]. Pro et Contra, 2006, No.2-3. Pp. 13-18.

13. Pavlova L.P., Ponkratov V.V., Bloshenko T.A., Efimov A.V., Jumaev M.M. Nalogooblozhenie nedropol'zovanija V Rossijskoj Federacii [Taxation of subsoil use in the Russian Federation]. Moscow, Voentehinizdat, 2009. 496 p.

14. Pavlova L.P., Ponkratov V.V. Sovershenstvovanie NDPI po nefti [Improving the MET on oil]. Finansy Finance, 2008. no.6, pp. 36-40.

15. Perchik A.I. Nalogooblozhenie neftegazodobychi. Pravo. Jekonomika [Taxation of oil and gas. Law. Economy]. Moscow, Nestor Academic Publishers, 2004.

16. Ponkratov V.V. Nalogovyj manevr v neftjanoj otrasli Rossii [Tax maneuver in the Russian oil production industry]. Neftyanoe khozyaistvo - Oil Industry, 2014, no.9, pp. 58-61.

17. Ponkratov V.V. Sovershenstvovanie sistemy nalogooblozhenija dobychi nefti i gaza $\mathrm{s}$ uchetom uglevodorodnogo potenciala rossijskoj ekonomiki [Improvement of the system of taxation of oil and gas production in view of the hydrocarbonic potential of the Russian economy]. Nalogi i finansovoje pravo, 2012, no.7, pp. 223-229.

18. Ponkratov V.V. (2013). Taxation of oil and gas production in the Russian Federation: current status and future forecast. Interdisciplinary Studies Journal, Vol 3, no.2, 110-117.

19. Ponkratov V.V. Sovershenstvovanie nalogooblozhenija dobychi nefti [Improvement of the system of taxation of oil production]. Finansy Finance, 2011, no.6, pp. 38-40.

20. Popov V.V., Safonov Ju.G. Mineral'no-syr'evaja baza toplivno-energeticheskogo i metallurgicheskogo kompleksov Rossii: sostojanije, perspektivy osvoenija i razvitija (2006-2020-2050 gg.) [Mineral resources of fuel and energy and metallurgical complexes in Russia: state and development prospects of development (20062020-2050 years.)]. Moscow, IGEM RAN, 2006.

21. Razovskij Ju.V. Sverhpribyl' nedr [Excess profits subsoil]. Moscow, Editorial URSS, 2001.

22. State Report "The status and use of mineral resources of Russia in 2014". Moscow, Ministry of Natural Resources and Environment, 2015.

23. Van der Ploeg, F. (2010). Aggressive oil extraction and precautionary saving: Coping with volatility. Journal of Public Economics, 94, Issue 5-6, 421-433. 
В. В. Понкратов, канд. экон. наук, 2. Москва, Россия

\title{
НАЛОГООБЛОЖЕНИЕ ДОБЫЧИ НЕФТИ В РОССИИ - ПОСЛЕДСТВИЯ НАЛОГОВОГО МАНЕВРА
}

\begin{abstract}
Аннотация. В статье проанализирована действующая система налогообложения добычи нефти в России, а также механизмы и последствия налоговых маневров 20132014 гг. в нефтяной отрасли, так как в ближайшие годы страны Таможенного союза должны выработать единую политику в сфере топливно-энергетического комплекса и гармонизировать системы вывозных таможенных пошлин на нефть и продукты ее переработки. Сформулированы предложения по совершенствованию системы налогообложения добычи нефти в России с учетом перспектив развития отрасли и существующих ресурсных ограничений, а также значения для формирования консолидированного бюджета в части таких налогов, как налог на добычу полезных ископаемых, налог на прибыль, экспортная пошлина и платежи, установленные Законом РФ «О недрах» от 21 февраля 1992 г. № 2395-1. Правительство в 2011-2014 гг. уделяло повышенное внимание вопросам совершенствования основных положений и нормативного регулирования налога на добычу полезных ископаемых, но последние новации повлекли доминирование фискальной функции этого налога. Положение в отрасли нуждается в обратном - растет потребность в инвестициях в разработку месторождений в новых нефтегазовых провинциях, развитие транспортных и перерабатывающих мощностей. При разработке концепции налогообложения добычи углеводородного сырья необходимо основываться на следующих подходах: налогообложение результата деятельности компаний; стимулирование рационального пользования недрами и наиболее полного извлечения основных и попутных компонентов; экономическая и бюджетная эффективность; простота администрирования.
\end{abstract}

Ключевые слова. Налогообложение добычи углеводородного сырья; налог на добычу полезных ископаемых; таможенная пошлина; налоговый маневр; ресурсная база нефтегазовой промышленности России; гармонизация налогообложения в рамках Таможенного союза.

\section{Сведения об авторе}

Понкратов Вадим Витальевич - кандидат экономических наук, директор Центра финансовой политики Института финансово-экономических исследований Финансового университета при Правительстве Российской Федерации, г. Москва, Россия (125993, ГСП-3, г. Москва, просп. Ленинградский, 49); e-mail: vadim.ponkratov@gmail. com. 